\title{
The Global Boundary Stratotype Section and Point for the base of the Danian Stage (Paleocene, Paleogene, "Tertiary", Cenozoic): auxiliary sections and correlation
}

1 Departamento de Ciencias de la Tierra, IUCA, Universidad de Zaragoza. E-50009 Zaragoza, Spain. Email; emolina@unizar.es; laia@unizar.es; ias@unizar.es; josearz@unizar.es

2 Département de Geologie, Faculté des Sciences de Tunis, 2092 Tunis El Manar,Tunisia.Email: gnoujoud@yahoo.fr; dalila.zaghbib@fst.rnu.tn 3 Instituto Mexicano del Petróleo. Eje Lázaro Cárdenas, 152, Mexico D.F., 07730, Mexico.Email:mgrajal@imp.mx; gmurill@imp.mx

The Global Stratotype Section and Point (GSSP) for the Cretaceous/Paleogene (K/Pg) boundary was defined at the base of the boundary clay at a section near El Kef, Tunisia, but the outcrop became quite deteriorated. In order to better characterize the boundary and to solve problems of correlation, several auxiliary sections are designed and described in detail including: Aïn Settara and Ellès in Tunisia, Caravaca and Zumaya in Spain, Bidart in France and El Mulato and Bochil in Mexico. These sections are the most continuous, expanded and representative of marine sedimentation in areas proximal and distal to the Chicxulub meteorite impact site. In addition, these sections are classical, very well known, physically accessible, have been exhaustively studied and allow a very detailed global correlation. The correlation criteria used were the meteorite impact evidence (Ir anomaly, Ni-rich spinel, etc.) and the mass extinction of planktic micro- and nannofossils. Furthermore, it was proposed that the K/Pg boundary is marked exactly by the moment of the meteorite impact, which implies that all the sediments generated by the impact belong to the Paleogene. While in distal areas to the impact site the K/Pg boundary coincides with a millimetre-thick rusty layer, in proximal areas the $\mathrm{K} / \mathrm{Pg}$ boundary correlates to the base of a metre-thick Clastic Unit, including a thick calcareous breccia in the sections closer to the impact crater.

\section{Introduction}

An International Working Group was established to formally define a GSSP for the K/Pg boundary and, after studying several sections in detail (El Kef in Tunisia, Zumaya in Spain, Brazos in USA and Stevns Klint in Denmark), the chairwoman of the K/Pg Boundary Working Group submitted a written proposal to the International Commission on Stratigraphy (ICS). The GSSP of the K/Pg boundary was defined at the base of the boundary clay at the section near El Kef, Tunisia. This proposal was approved by the ICS in 1990 and was ratified by the International Union of Geological Sciences in 1991.

Nevertheless, its publication in a prestigious stratigraphical journal of wide distribution, which is the final step in the definition of the GSSP, was not made until the chairman of the International Subcommission on Paleogene Stratigraphy (ISPS), in collaboration with several colleagues, including the chairwoman of the K/Pg Boundary Working Group, reviewed the studies since the original proposal and revised the main criteria defining the K/Pg boundary (Molina et al. 2006). However, this official publication of the GSSP did not include any auxiliary sections in which the event could be studied in other facies and different paleobiogeographic contexts, allowing a global correlation. Furthermore, deterioration of the outcrops at the El Kef section (Remane and Adatte, 2002), which makes necessary to trench and difficult to find the GSSP, requires assigning auxiliary sections where the $\mathrm{K} / \mathrm{Pg}$ boundary is better exposed.

The aim of this paper is to describe the most suitable sections, which are considered auxiliary sections of the K/Pg boundary, to establish the correlation between areas distal and proximal to the Chicxulub meteorite impact site and to solve problems of erroneous placement of the K/Pg boundary.

\section{Auxiliary sections}

According to Remane et al. (1996), the auxiliary sections proposed here are subordinate to the GSSP and fulfill most of the requirements to characterize a GSSP. The auxiliary sections described below are located in three different regions across the world (Fig.1): around El Kef (Tunisia), where the GSSP was defined (Aïn Settara and Ellès), in southwestern Europe where other suitable sections were proposed (Bidart, Caravaca, Zumaya) and around the Gulf of Mexico, close to the meteorite impact crater (Bochil and El Mulato). 


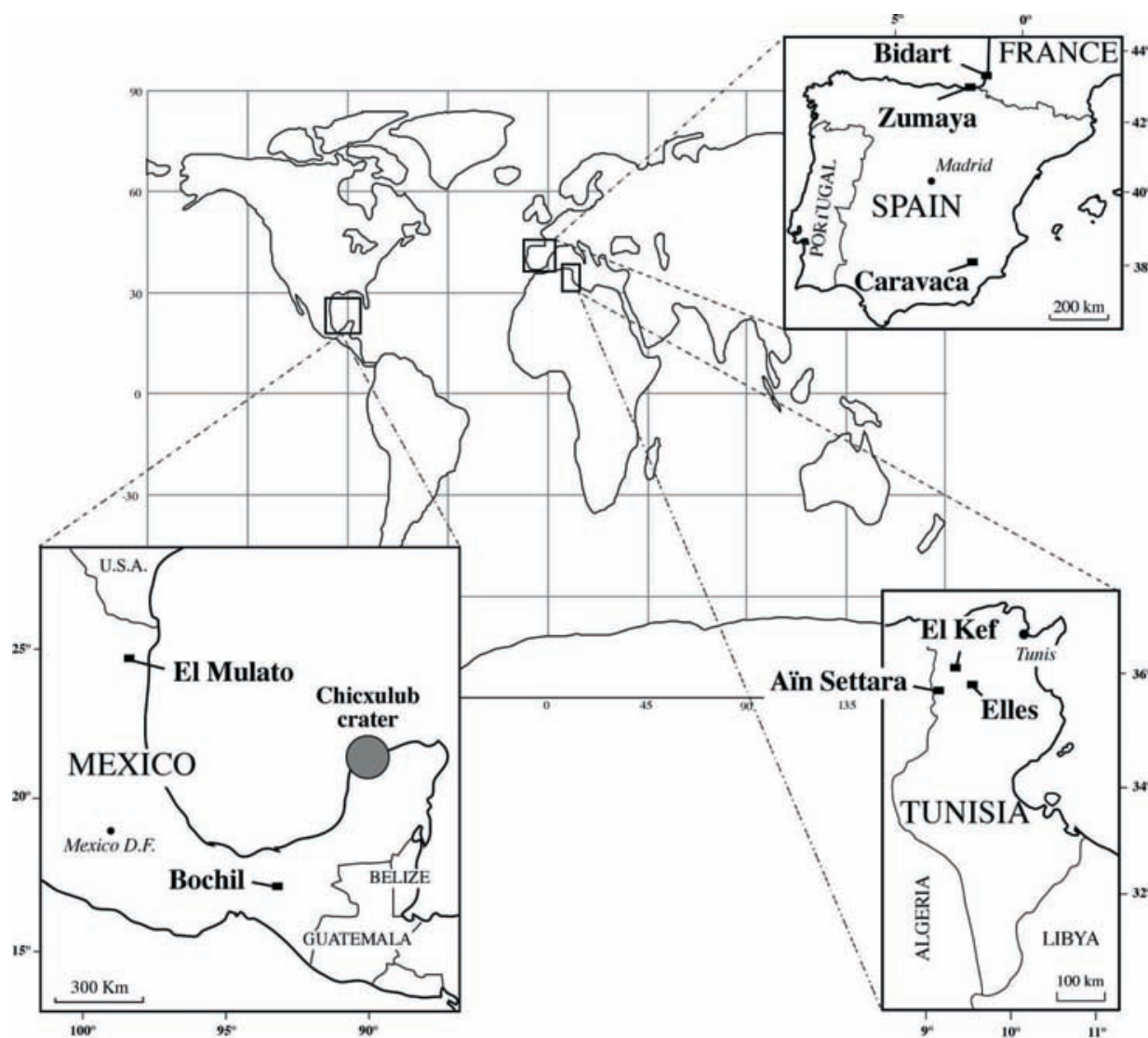

Figure 1. Geographical location of the El Kef GSSP and the auxiliary sections proposed in this paper.

\section{Aïn Settara section (Tunisia)}

The Aïn Settara section is located in Central Tunisia, $50 \mathrm{~km}$ south of the El Kef K/Pg GSSP, in the region between Kalaat Senan, Tajerouine and Kalaa Khasba (Fig.1). Its geographical coordinates are: latitude $35^{\circ} 80^{\prime} \mathrm{N}$ and longitude $9^{\circ} 50^{\prime} \mathrm{E}$.

The K/Pg boundary lies within the middle part of the marly El Haria Formation and is exposed in a $100 \mathrm{~m}$ high steep flank of a deeply incised gully (Plate 1A). It occurs at about $80 \mathrm{~m}$ above the gully, is horizontally traceable for more than $200 \mathrm{~m}$ and its exposure is excellent. The El Haria Formation includes several units in this region, two of which are at the $\mathrm{K} / \mathrm{Pg}$ transition: that exposed at the Sidi Nasseur location includes the base of the boundary clay and the underlying Aïn Settara marly unit. At the Aïn Settara region, this unit consists of dark grey marls rich in jarosite nodules, with alternating thick whitish and more carbonate-rich beds. The Sidi Nasseur Unit is composed of alternating blue grey marls and thin whitish limestone beds.

In 1996, Arz and Arenillas described in their doctoral theses the Maastrichtian and Danian planktic foraminiferal assemblages of the Aïn Settara section, and documented a catastrophic mass extinction event coinciding with the K/Pg boundary (Arenillas et al. 2000). The $\mathrm{K} / \mathrm{Pg}$ boundary at Aïn Settara was multidisciplinary studied by Dupuis et al. (2001), who carried out micropaleontological (planktic foraminifera, calcareous nannofossils, dinoflagellate cyst), mineralogical, and geochemical analyses. Mukhopadhyay et al. (2001) found evidence of extraterrestrial Helium-3 and suggested a short duration of the Cretaceous-Paleogene boundary event. The uppermost $2 \mathrm{~cm}$ of the Maastrichtian consists of grey clayey marls; the K/Pg boundary consists of a yellowish to orangecoloured layer with cosmic markers and is overlaid by a 0.5 m-thick dark grey clay. Since the first Danian species occur gradually over an extensive stratigraphic interval in the lower Danian from Aïn Settara, and all the planktic foraminiferal biozones and subzones of the $\mathrm{K} / \mathrm{Pg}$ transition have been recognized at the Aïn Settara section (Molina et al. 1998; Arenillas et al. 2000; Arz and Molina, 2002), this section is considered one of the most continuous and expanded marine $\mathrm{K} / \mathrm{Pg}$ boundary sections in the Tethys area. The identified planktic foraminiferal biozones and subzones of the K-Pg transition at the Ain Settara section include - the upper Maastrichtian Plummerita hantkeninoides Subzone, and the lower Danian Guembelitria cretacea Zone,

- Parvularugoglobigerina eugubina Zone and Parasubbotina pseudobulloides Zone (Molina et al. 1998; Arenillas et al. 2000, - Arz and Molina, 2002). Luciani et al. (2002) claimed to have found evidence of a gradual mass extinction across the $\mathrm{K} / \mathrm{Pg}$ boundary and several hiatuses in the lowermost Danian. However, Arenillas et al. (2004) restudied the section and neither the extended pattern of extinction nor the hiatuses mentioned by Luciani et al. (2002)

could be reproduced. On the contrary, a sudden catastrophic mass extinction pattern was confirmed and all the zones as well as new subzones (the uppermost Maastrichtian Plummerita hantkeninoides Subzone, and the lowermost Danian Hedbergella holmdelensis, Parvularugoglobigerina longiapertura, Parvularugoglobigerina sabina, Eoglobigerina simplicisima and Eoglobigerina trivialis Subzones) were recognized.

The K/Pg boundary interval is characterized with calcareous nannofossils by the $M$. prinsii, $O$. operculata and $N$. romeini zones. With dinoflagellate cysts it can be divided into a Cretaceous unnamed interval, a transitional interval and the lowermost Danian D. californicum Zone (Dupuis et al. 2001). The sudden change in small benthic foraminifera, from a typical mesotrophic oceanic episode in the late Maastrichtian to an oligotrophic oceanic episode in the earliest Paleogene, suggests an important disruption in the stratification of the water column and in the food-web coinciding with the planktic mass extinction at the K/Pg boundary (Alegret et al. 2002a, 2004b; Peryt et al. 2002, 2004). The stratigraphic distribution of Ir and Ni-rich spinels shows that the cosmic imprint reported worldwide at the $\mathrm{K} / \mathrm{Pg}$ boundary is also recorded in the Aïn Settara section.

\section{Ellès section (Tunisia)}

This section is located in Central Tunisia, $56 \mathrm{~km}$ southeast of El Kef K/Pg GSSP, between Houch El Balti and the village of Ellès, and $3 \mathrm{~km}$ east of Ellès (Fig.1). Its geographical coordinates are: latitude $35^{\circ} 56^{\prime} 40.4^{\prime \prime} \mathrm{N}$ and longitude $9^{\circ} 4^{\prime} 49.9^{\prime \prime} \mathrm{E}$. 

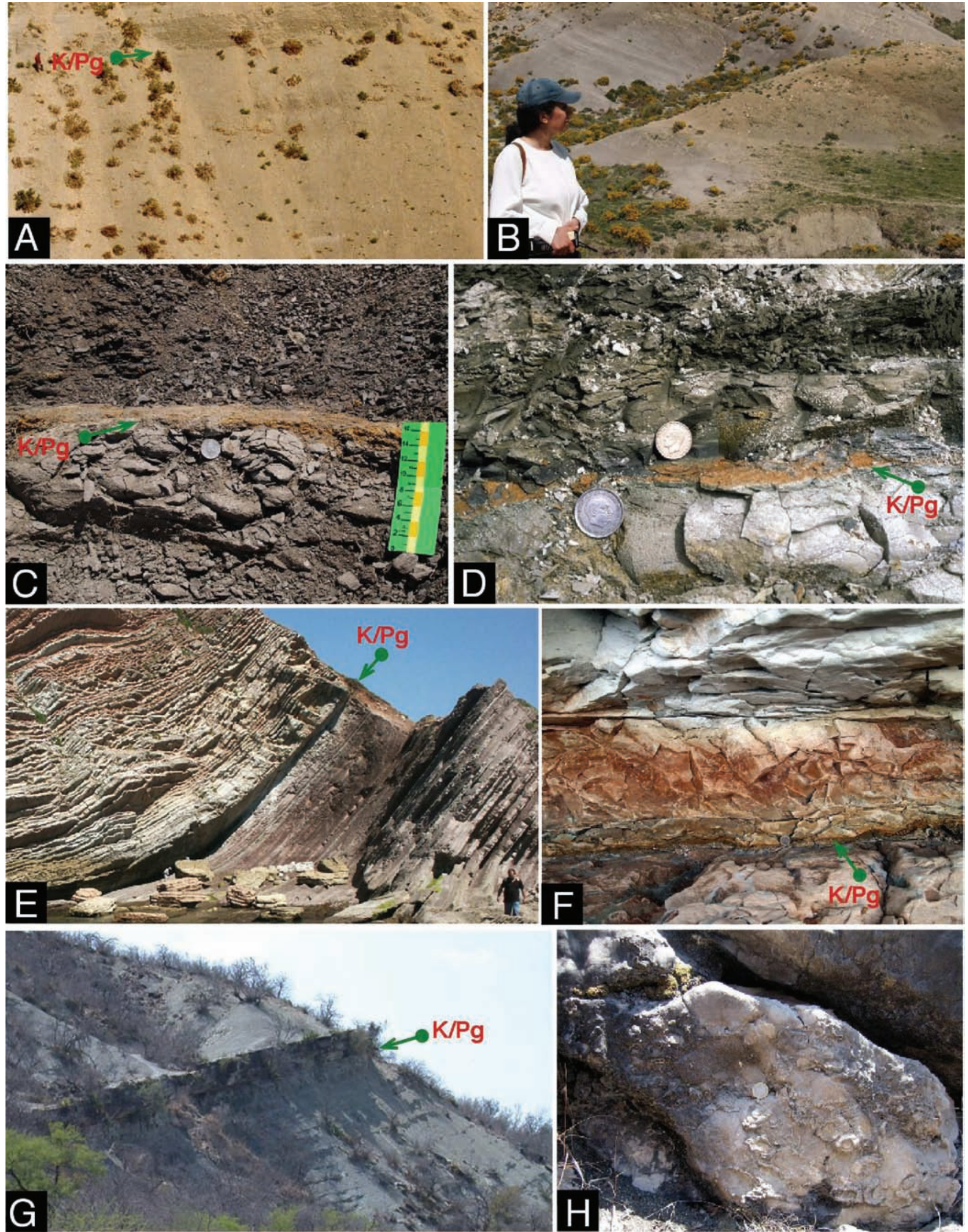

Plate 1. Photographs of the auxiliary section outcrops. A: Panoramic view of the Ä̈n Settara section. B: Panoramic view of the Ellès section. C: Detail of the K/Pg boundary at Ellès (above the coin is the rusty red layer). D: Detail of the K/Pg boundary at Caravaca (between the coins is the rusty red layer). E: Panoramic view of the Zumaya section. F: Detail of the K/Pg boundary at Bidart (the arrow points the rusty red layer). G: Panoramic view of the El Mulato section. H: Detail of the K/Pg boundary breccia at Bochil. 
The K/Pg transition is continuous and well exposed along the northwestern side of the Ellès syncline and is included into the El Haria Formation marls (Plate 1B). In 1978, Saïd described the Ellès section in her doctoral thesis, studied the upper Maastrichtian and Paleocene microfossils (planktic and benthic foraminifera and ostracods), and concluded that the $\mathrm{K} / \mathrm{Pg}$ transition is continuous. In 1994, Karoui and Zaghbib-Turki pointed out that the thin layer of the $\mathrm{K} / \mathrm{Pg}$ boundary is rich in microscopic glassy spheres. In 1998 these authors confirmed, with the collaboration of Rocchia and Robin, that the rust-colored layer is rich in Ir and Ni-rich spinel crystals. In 1999, a high resolution sampling was carried out by Karoui-Yaakoub in her doctoral thesis. The author detailed the K/Pg transitions and confirmed that the $\mathrm{K} / \mathrm{Pg}$ transition at the Ellès section is continuous. The ostracods were studied by Saïd-Benzarti (1998) and the nannofossils by Gardin (2002).

The K/Pg planktic foraminifera across a $7.5 \mathrm{~m}$ interval were also studied by Arz et al. (1999a), who identified a hiatus between the Pv. eugubina and Ps. pseudobulloides zones, $5.5 \mathrm{~m}$ above the K/Pg boundary. Nevertheless, the $\mathrm{K} / \mathrm{Pg}$ boundary is continuous and is one of the most expanded marine sections known so far, since the boundary clay is $1.4 \mathrm{~m}$ thick. Its base consists of a $3 \mathrm{~cm}$-thick azoic yellowish clay with quartz, iron oxides and jarosite (Plate 1C). The sudden and catastrophic mass extinction at this level coincides with a shift in $\delta^{13} \mathrm{C}$, the increase in total organic carbon (TOC) and the decrease in $\% \mathrm{CaCO}_{3}$. The section was also studied in detail by Zaghbib-Turki et al. (2000, 2001), recognizing the relevant event of the K/Pg boundary and proposing it as parastratotype. Furthermore, Karoui-Yaakoub et al. (2002) revised this section and concluded that the K/Pg interval is complete and similar to the El Kef section. Another section (Ellès II), located at $100 \mathrm{~m}$ toward the south was described by Keller et al. (2002), who analysed the paleoecology of the K/Pg boundary mass extinction based on planktic foraminifera. The mineralogy of this section was studied by Stüben et al. (2002).

\section{Caravaca section (Spain)}

The Caravaca section is located in south Spain (Murcia region), about $3 \mathrm{~km}$ south of the town of Caravaca in the Barranco del Gredero ravine (Fig.1). Its geographical coordinates are: latitude $39^{\circ} 5^{\prime} 19^{\prime \prime} \mathrm{N}$, and longitude $1^{\circ} 52^{\prime} 26^{\prime \prime} \mathrm{W}$.

The section lies in the Betic Cordillera, Subbetic Zone and the $\mathrm{K} / \mathrm{Pg}$ boundary is in the Jorquera Formation, composed of gray marls and clay. In 1975, Abtahi initially studied the foraminifera in his master thesis. Smit $(1977,1979)$ found that the K/Pg boundary clay was more expanded than in the Gubbio section (Italy) and discovered a planktic foraminiferal association between the Abathomphalus mayaroensis Zone and the Pv. eugubina Zone, which he called G. cretacea Zone. Later, Smit and Hertogen (1980) identified a 2 to $3 \mathrm{~mm}$-thick rusty red layer (Plate 1D) and the Ir anomaly. Their study was published one month before the seminal paper by Alvarez et al. (1980), although they did not claim priority because the theory was previously communicated in a congress in 1979 by the Alvarez team. The red rusty layer also contains altered microtectites (Smit and Klaver, 1981), as well as anomalous concentrations in $\mathrm{Co}, \mathrm{Cr}, \mathrm{Ni}$, As, Sb, and Se (Smit and Ten Kate, 1982). Many other mineralogical and geochemical analyses were accomplished finding overwhelming meteoritic impact evidence (Montanari et al. 1983; De Paolo et al. 1983; Rampino and Reynolds, 1983; Kyte et al. 1985; Vannuci et al. 1990; Robin et al. 1991; Schmitz, 1994; Ortega Huertas et al. 1995;
Martínez Ruiz et al. 1997; Shukolyukov and Lugmair, 1998; Arinobu et al. 1999).

The planktic foraminifera at this section were studied in detail by Canudo et al. (1991), Kaiho and Lamolda (1999) and Arz et al. (2000). They recognized the uppermost Maastrichtian $P$. hantkeninoides subzone, the lowermost Danian G. cretacea, Pv. eugubina and Ps. pseudobulloides zones, and identified a catastrophic extinction pattern similar to the one found in Tunisia. A geologically instantaneous extinction event in small benthic foraminifera was also documented at the K/Pg boundary by Coccioni et al. (1993) and Coccioni and Galeotti (1994) in the Caravaca section. Benthic foraminifera indicate a middle bathyal depth of deposition for the $\mathrm{K} / \mathrm{Pg}$ interval at Caravaca. A temporary faunal turnover consisting of the reorganization of the benthic foraminiferal community structure, but no mass extinction in small benthic foraminifera, starting at the $\mathrm{K} / \mathrm{Pg}$ boundary has been reported from this section (Coccioni et al. 1993; Alegret, 2007). Furthermore, these authors documented a very short interval of high-food, low oxygen conditions in the lowermost Danian at Caravaca. The calcareous nannoplankton was studied by Gardin and Monechi (1998) concluding that Cretaceous species occurring after the K/Pg boundary are mainly reworked. Furthermore, bioturbation across the boundary clay has been reported by Rodriguez-Tovar and Uchman (2006), which is the cause of the Cretaceous nannofossils and foraminifers reworked in the lowermost Paleogene.

\section{Zumaya section (Spain)}

The Zumaya section is located in northern Spain (Guipúzcoa province, Basque country), near the village of Zumaya at the cliff of Punta Aitzgorri (Fig.1). Its geographical coordinates are: latitude $43^{\circ} 17^{\prime} 56^{\prime \prime} \mathrm{N}$ and longitude $2^{\circ} 16^{\prime} 04^{\prime \prime} \mathrm{W}$.

The lithology consists of purple marls at the upper Maastrichtian, dark grey clays at the $\mathrm{K} / \mathrm{Pg}$ boundary and red marly limestones at the Danian (Plate 1E). The section is very well known because of its superb exposure along the beach and cliff just north of Zumaya. It was considered a suitable candidate to define the K/Pg boundary and in the vote process resulted second in position after the El Kef section. The K/Pg boundary coincides with a 2-3 $\mathrm{cm}$-thick calcite vein of supergenetic nature, which is overlain by a $7-8 \mathrm{~cm}$ of dark grey clays and eventually by $25 \mathrm{~cm}$ of grey marls. Mineralogical and geochemical studies were conducted by Mount et al. (1986) and Ortega Huertas et al. (1995).

The K/Pg interval was biostratigraphically studied by Percival and Fischer (1977), Lamolda (1990), Fondecave-Wallez et al. (1995a), Apellaniz et al. (1997) and Arenillas et al. (1998), establishing the calcareous nannoplankton and planktic foraminiferal biozonations. A high-resolution sampling was carried out by Arz et al. (1999b) and the biostratigraphic, quantitative and taphonomic study of planktic foraminifera allowed to corroborate the sudden catastrophic pattern of mass extinction at the $\mathrm{K} / \mathrm{Pg}$ boundary. Furthermore, Kuhnt and Kaminski (1993) analyzed the agglutinated benthic foraminiferal changes and concluded that a deep-water agglutinated foraminiferal turnover indicates a drastic decrease in surface productivity and a collapse of the food-web in coincidence with the K/Pg boundary. Ammonites were also studied by Ward et al. (1986) showing an apparent extinction before the K/Pg boundary. However, more intensive sampling demonstrated that the extinction of ammonites also coincides with the mass extinction at the K/Pg boundary (Ward et al. 1991). 


\section{Bidart section (France)}

The Bidart section is located in southwestern France, between Hendaye and Biarritz, on the Bidart beach named Pavillon Royal or Caseville (Fig.1). Geologically, it is placed in the Pyrenees within the Basque-Cantabrian Basin. Its geographical coordinates are: latitude $43^{\circ} 26^{\prime} 54^{\prime \prime} \mathrm{N}$, and longitude $1^{\circ} 35^{\prime} 16^{\prime \prime} \mathrm{W}$.

The Maastrichtian sediments correspond to the "Bidart marls", composed of grey marls and calcareous marls with abundant foraminifera and scarce echinoids. The uppermost $2 \mathrm{~cm}$ of the Maastrichtian consist of grey clayey marls. The K/Pg boundary is marked by a red ferruginous $2 \mathrm{~mm}$-thick lamina and a $6 \mathrm{~cm}$-thick layer of dark red clays (Plate 1F). The overlying sediments consist of brownish clays, grey marls and red limestones. This section is considered one of the most complete $\mathrm{K} / \mathrm{Pg}$ boundary sections in southwestern Europe (Haslett, 1994; Peybernès et al. 1996). According to Renard et al. (1982), the Maastrichtian of Bidart was deposited under Tethyan influences, whereas the Paleocene was primarily influenced by the North Atlantic.

The Bidart section was initially investigated by means of calcareous nannofossils by Martini (1961) and by Lézaud in his doctoral thesis in 1967. It has been also studied by numerous authors from different points of view such as stable isotope analysis (Romein and Smit, 1981; Renard et al. 1982; Nelson et al. 1991), Ir content (Smit and Ten Kate, 1982; Bonté et al. 1984), biostratigraphy (e.g., Bonté et al. 1984; Delacotte et al. 1985 and Minoletti et al. 2004), sedimentology (Peybernès et al., 1997), magnetostratigraphy (Galbrun, 1997; Galbrun and Gardin, 2004), geochemistry (Renard et al. 1982; Bonté et al. 1984; Rocchia et al. 1987), and chronostratigraphy (Galbrun et Gardin, 2004). Detailed biostratigraphical studies across the K/Pg interval were based on calcareous nannofossils (e.g. Perch-Nielsen, 1979; Gorostidi and Lamolda, 1995; Seyve, 1990), confirming the continuous deposition record at the Bidart section, and on planktic foraminifera (Haslett, 1994; FondecaveWallez et al. 1995b; Apellaniz et al., 1997). Its macrofaunal content (ammonites and inoceramids) was studied by Ward (1988) and Ward and Kennedy (1993). Benthic foraminiferal assemblages across the $\mathrm{K} / \mathrm{Pg}$ boundary indicate deposition in the upper-middle part of the slope, and reflect mesotrophic conditions during the late Maastrichtian and a strong decrease in the food supply to the sea floor coincident with the K/Pg boundary (Alegret et al. 2004a).

\section{El Mulato section (Mexico)}

The El Mulato section is located in northeastern Mexico (Tamaulipas State), $500 \mathrm{~m}$ north of El Mulato village (Fig.1). Its geographical coordinates are: latitude $24^{\circ} 54^{\prime} \mathrm{N}$ and longitude $98^{\circ} 57^{\prime} \mathrm{W}$.

Between the marly Upper Cretaceous Méndez Formation and the marly Lower Paleogene Velasco Formation, there is a nearly 2 mthick Clastic Unit (Plate 1G) that has been interpreted as the result from impact-generated tsunami currents (Smit et al. 1996).

The lower part of this unit is an $8-10 \mathrm{~cm}$-thick tabular bed with abundant microtectites and marly muddy pebbles from the Méndez Formation. This bed is overlain by a fining-upward 30 -cm thick bed of medium to coarse-grained ochre sandstones. It continues with a $50-\mathrm{cm}$ thick tabular body of medium-grained ochre sandstones. Above these, there are three beds comprising $40-\mathrm{cm}$ of medium to finegrained ochre sandstones. The deposit continues with two tabular beds comprising $35 \mathrm{~cm}$ medium to fine-grained sandstones. The
Clastic Unit is topped by $30 \mathrm{~cm}$ of tabular fine-grained ochre sandstone. This section is one of the most representative $\mathrm{K} / \mathrm{Pg}$ boundary outcrops in the Gulf of Mexico.

The El Mulato section has been studied by numerous authors from different points of view, including lithostratigraphy, sedimentology and mineralogy (e.g. Smit et al. 1992, 1996; Adatte et al. 1996). Calcareous nannofossil biostratigraphic studies were carried out by Sánchez-Ríos et al. (1993) and Pospichal (1996), who identified the uppermost Maastrichtian Micula prinsii Zone and the lowermost Paleocene Zone NP1 of calcareous nannofossils. Planktic foraminiferal biostratigraphic studies were carried out by López-Oliva and Keller (1996) and Arenillas et al. (2004), and preliminary ichnofossil data were reported by Ekdale and Stinnesbeck (1998).

Benthic foraminifera from the Méndez and Velasco formations indicate lower bathyal paleodepths (Alegret et al. 2001, 2002b). The Clastic Unit, in contrast, contains platform sediments and faunas mixed with microtectites. This indicates that it was allochtonously deposited, triggered by the $\mathrm{K} / \mathrm{Pg}$ boundary meteorite impact. Planktic foraminifera were affected by a catastrophic extinction at the $\mathrm{K} / \mathrm{Pg}$ boundary, whereas benthic foraminifera show reorganization of the community structure due to changes in the food supply to the sea floor after the asteroid impact.

\section{Bochil section (Mexico)}

The Bochil section is located in southeastern Mexico (Chiapas State), about $9 \mathrm{~km}$ northeast from the town of Bochil, along the road to the PEMEX Soyalo-1 well (Fig.1). Its geographical coordinates are: latitude $17^{\circ} 00^{\prime} 36^{\prime \prime} \mathrm{N}$, and longitude $92^{\circ} 56^{\prime} 44^{\prime \prime} \mathrm{W}$.

This section is one of the most representative K/Pg boundary outcrops in southern Mexico, containing a Clastic Unit with a thick impact calcareous breccia (Plate $1 \mathrm{H}$ ) due to its relatively close position to the Chicxulub crater. This unit is also called Breccia Unit, " $\mathrm{K} / \mathrm{Pg}$ boundary cocktail" or Clastic Complex Unit because it includes a mixture of reworked microfossils, impact-derived materials and heterogeneous carbonate lithoclasts (Grajales-Nishimura et al. 2003). This K/Pg stratigraphic horizon is underlain by deep-water facies of the upper Maastrichtian Jolpabuchil Formation. The K/Pg boundary has an upward-fining clastic sequence that was subdivided into three main subunits by Arenillas et al. (2002). These authors conclude that this section is similar to the one in Guayal (Tabasco) described by Grajales-Nishimura et al. (2000).

The planktic foraminiferal assemblages in the uppermost autochthonous Maastrichtian marls of the Jolpabuchil Formation belong to the upper part of the G. gansseri Zone (Arenillas et al. 2006). This datum indicates an erosional hiatus due to scouring on the sea floor during the sudden emplacement of the Clastic Complex Unit that affected the upper Maastrichtian sediments. The Clastic Unit is very thick and can be divided, from bottom to top, into 4 subunits. The basal subunit consists of a nearly $80 \mathrm{~m}$-thick, very coarse-grained carbonate breccia containing blocks up to $2 \mathrm{~m}$ in diameter. The second subunit is a $5 \mathrm{~m}$-thick fine-grained calcareous breccia and coarsegrained calcareous sandstone mixed with impact materials (e.g. microtektites and shocked quartz). The third subunit is nearly $1 \mathrm{~m}$ thick and consists of very fine-grained yellow rippled ejecta-rich sandstone and siltstone. The uppermost subunit is a thin yellow-red shaly layer that represents the finest ejecta, containing the Ir anomaly and Ni-rich spinels crystals. A 6-8 cm-thick dark clay bed overlies the Clastic Complex Unit, and marks the base of the Soyaló Formation. 
The lowermost centimeters of this dark clay bed belong to the H. holmdelensis Subzone (= Biozone P0 by Berggren and Pearson, 2005), showing the continuity across the impact-linked Clastic Complex Unit and the lowermost Danian sediments (Arenillas et al. 2006).

The Bochil section has been studied from different points of view such as mineralogy and geochemistry (Montanari et al. 1994), sedimentology and stratigraphy (Smit et al. 1996, 1999; GrajalesNishimura et al. 2000), lithoclast composition of the K-Pg boundary breccia (Grajales-Nishimura et al. 2003), and micropaleontology (Arenillas et al. 2002; Keller et al. 2003; Arenillas et al. 2006).

\section{Correlation and conclusions}

\section{Correlation by impact evidence}

The base of the boundary clay at the El Kef, where the GSSP for the $\mathrm{K} / \mathrm{Pg}$ was formally defined, consists of a mm-thick rusty layer with abundant Ni-rich spinels, scarce microtectites and shocked quartz (Plate 2) and anomalous values of the Ir content, as well as others less known impact evidence. These evidence has been also found at the Aïn Settara, Ellès, Caravaca, Zumaya and Bidart sections. In the Gulf of Mexico region impact evidence is distributed along a $\mathrm{m}$ to dm-thick clastic unit, such as the Clastic Unit at El Mulato (2 mthick) and the Clastic Complex Unit at Bochil (about 86 m-thick) (Fig.2).

The deposition of these clastic complex units is genetically linked to the Chicxulub meteorite impact event, which caused major coastal flooding, megatsunamis and destabilization of the continental margins of North America (e.g. Smit, 1999; Norris et al. Soria et al. 2001, 2002). The sudden emplacement of the Clastic Unit produced an erosional hiatus, which has been documented at the Bochil section. The hiatus just below the $\mathrm{K} / \mathrm{Pg}$ boundary is an irrelevant chronostratigraphical problem for proposing El Mulato and Bochil outcrops as auxiliary sections, since the base of the unit is the main defining criteria, and not the uppermost Maastrichtian autochtonous sediments. Nonetheless, a perfect section does not exist and these two Mexican sections fulfill most of the requirements to complement a GSSP.

The events chosen to define the GSSP of the K/Pg boundary were the meteorite impact and the simultaneous mass extinction of planktic micro- and nannofossils. Furthermore, it was proposed that the $\mathrm{K} / \mathrm{Pg}$ boundary is marked exactly by the moment of the meteorite impact and that all the sediments generated by the impact belong to the Paleogene (Molina et al. 2006). This proposal coincides with most of the authors who place the K/Pg boundary in the Gulf of Mexico sections at the base of the Clastic Unit (Smit and Romein, 1985; Smit et al. 1996; Smit, 1999; Arenillas et al. 2002; Arz et al. 2004). Nevertheless, controversial interpretations have been proposed in sections located around the impact site in the Gulf of Mexico, since some authors (Keller 1989; Keller et al. 2003) locate the K/Pg boundary at a different stratigraphic position. These authors put the $\mathrm{K} / \mathrm{Pg}$ boundary at the first occurrence of Danian planktic foraminifera in the Brazos river section (Keller, 1989) and above the Clastic Unit in other sections from the Gulf of Mexico. Their main argument is that the underlying Clastic Unit contains Maastrichtian planktic foraminifera. However, these foraminifera are reworked and cannot be used for chronostratigraphic studies. Furthermore, they claim to have found evidence of multiple meteorite impacts across the K/Pg
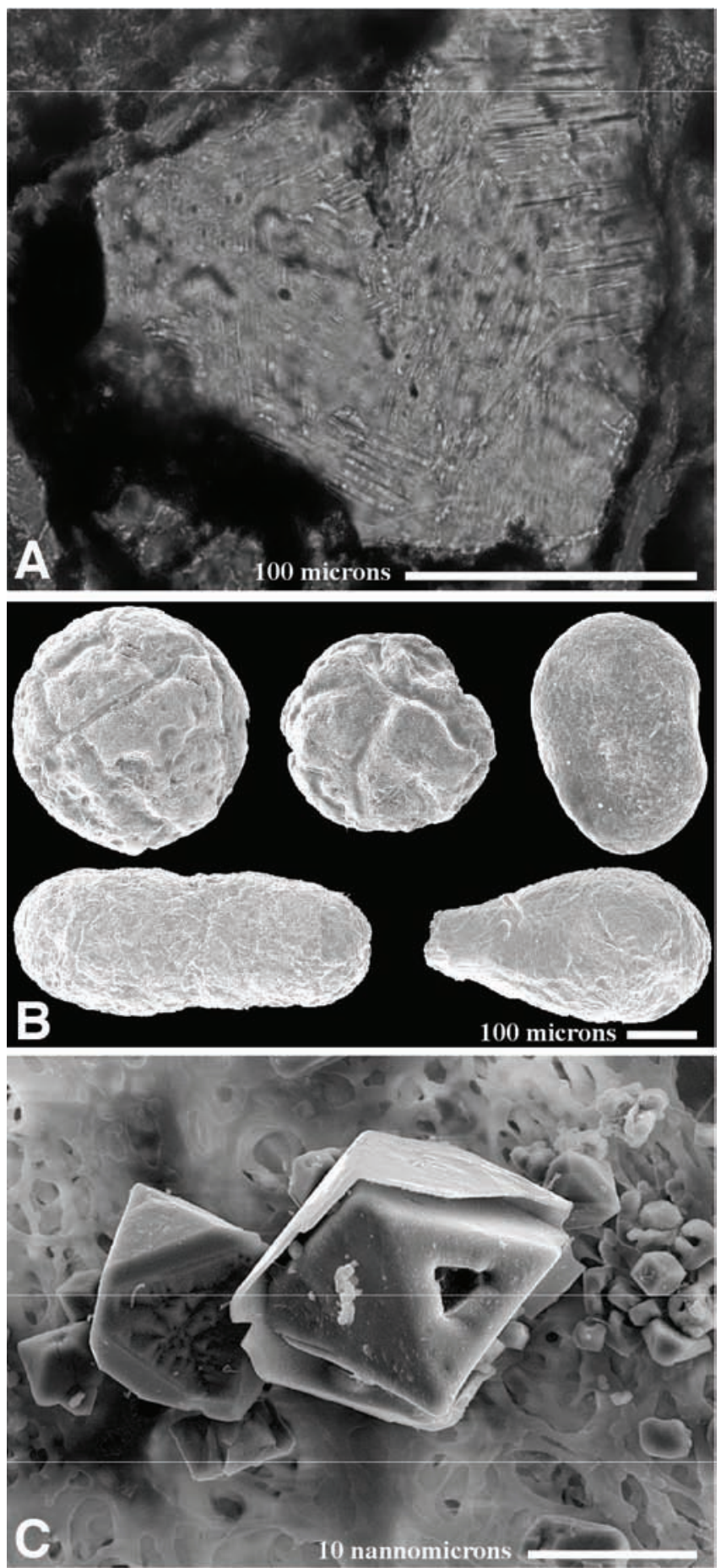

Plate 2. Photographs of the meteorite impact evidence. (A) Shocked quartz from Bochil section. (B) Microtektites from El Mulato section. (C) Ni-rich spinels from Caravaca section.

boundary (Keller et al. 2003) and that the Chicxulub impact predates the K/Pg boundary (Keller et al. 2004), but these claims are erroneous interpretations as demonstrated by Soria et al. (2001), Arz et al. (2004) and Arenillas et al. (2006), among others. Another erroneous criterion for chronostratigraphic correlation is the position of the Ir anomaly in the Gulf of Mexico, which is at the top of the Clastic Unit. This feature is due to the fact that the Ir was dissolved in the water and took longer to settle down in the bottom of the sea than the rest of the meteorite impact-derived materials and heterogeneous lithic fragments of the Clastic Unit. In the Gulf of Mexico region, around the impact 


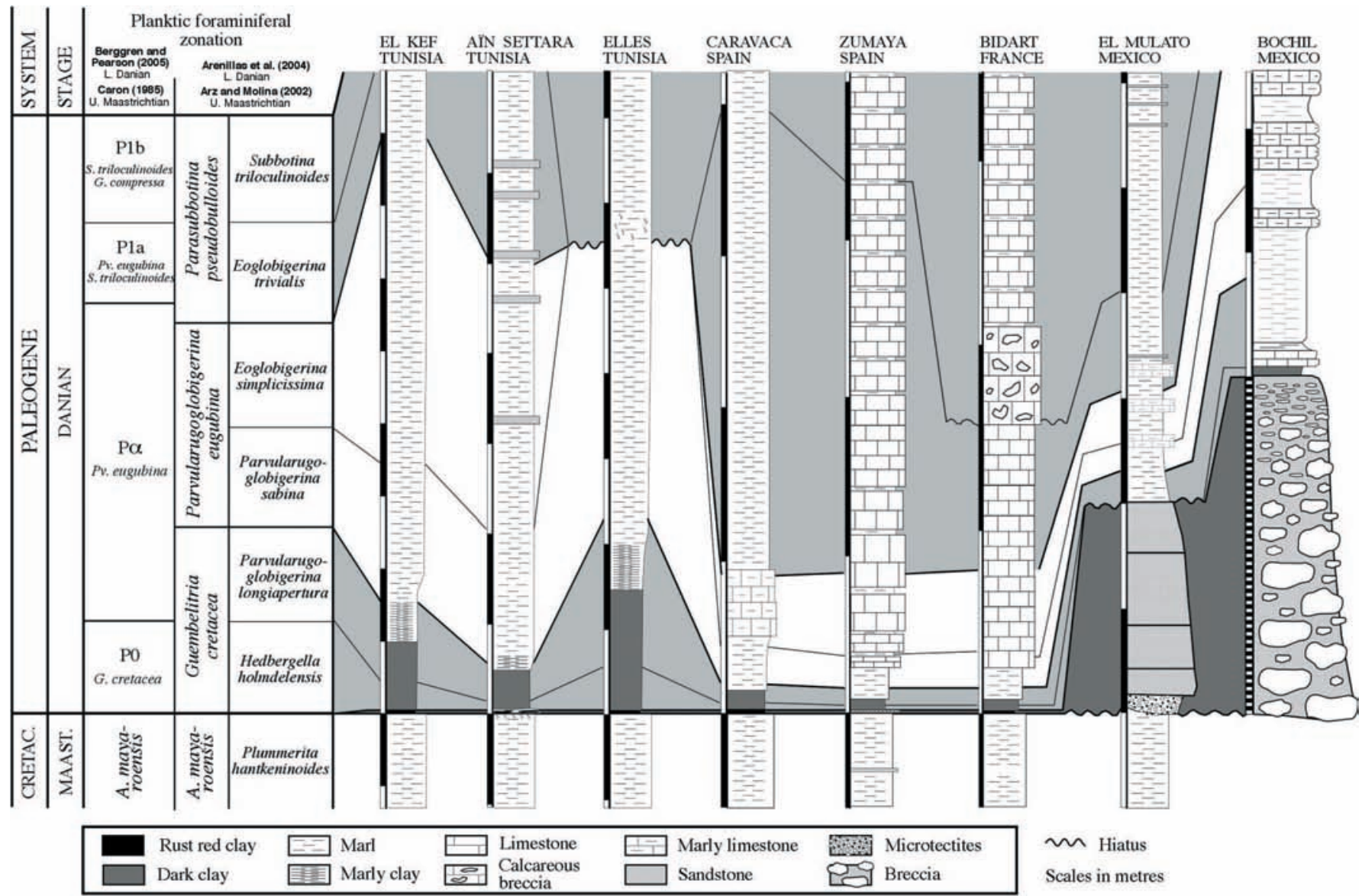

Figure 2. Biostratigraphical correlation among the GSSP at El Kef and the auxiliary sections proposed in this paper.

site, the Ir was concentrated when the Clastic Unit sedimentation rate slowed down towards the top of the unit. Therefore, the stratigraphic position of the Ir anomaly in the Gulf of Mexico seems to be different than that in El Kef GSSP, where clastic complex deposits are absent. This causes confusion in stratigraphic correlation at a world scale. Consequently, the $\mathrm{K} / \mathrm{Pg}$ boundary in areas proximal to the meteorite impact site must be placed at the base of the Clastic Unit, that is coinciding with the moment of the meteorite impact.

\section{Correlation by planktic foraminifera}

In most of the auxiliary sections proposed in this paper, the uppermost Cretaceous is lithologically and paleontologically similar. In general, it consists of marls with highly diversified planktic microand nannofossils that belong to the planktic foraminifera Abathomphalus mayaroensis Zone. Since the species A. mayaroensis is commonly a scarce deep dweller, the more frequent index-species Plummerita hantkeninoides is used to characterize the uppermost Maastichtian subzone. Nevertheless, in temperate sections such as Zumaya and Bidart P. hantkeninoides is absent and Pseudoguembelina hariaensis is used as an alternative subzonal marker (Arz and Molina, 2002). The highly diversified planktic foraminiferal fauna from the latest Cretaceous was suddenly affected by the K/Pg catastrophic mass extinction.

A dark clay layer, named the boundary clay, was deposited above the rusty layer and the Clastic Unit. Its thickness varies from about 1 $\mathrm{m}$ in the Tunisian sections to nearly $10 \mathrm{~cm}$ in the Caravaca, Zumaya, and Bidart sections. This layer characterizes most of the Guembelitria cretacea Zone. Although this clay was not found in the El Mulato section, it is present at the Bochil section, where it is 6-8 $\mathrm{cm}$ thick (Arenillas et al., 2006). The lowermost centimetres of this dark clay bed at Bochil belong to the H. holmdelensis Subzone (= Biozone $\mathrm{P} 0$ ), whose estimated duration is approximately $6 \mathrm{ky}$ (Arenillas et al., 2004). This duration is shorter than the estimated duration for the $\mathrm{K} / \mathrm{Pg}$ boundary clay deposition, about $10 \mathrm{ky}$, based on the nearconstant flux of extraterrestrial helium-3 (Mukhopadhyay et al. 2001). The boundary clay contains scarce and very small planktic foraminifera, which are disaster taxa that survived the K/Pg boundary crisis. The K/Pg event caused the extinction of about $90 \%$ of the planktic foraminiferal species. This percentage was calculated taking into account the occurrence of Cretaceous reworked foraminifers in the basal Paleogene due to bioturbation. This could have produced infiltration in the topmost Maastrichtian and reworking in the lowermost Danian (Rodríguez-Tovar and Uchman, 2006).

The Pv. eugubina Zone was defined at Gubbio (Italy) by Luterbacher and Premoli Silva (1964). The index species was found in a $2 \mathrm{~cm}$-thick clay layer, where Alvarez et al. (1980) discovered the Ir anomaly. The Gubbio section is a classical, very well known section, although it is too condensed to be designated as an auxiliary section. Nevertheless, the indurate limestone lithology allowed very relevant magnetostratigraphical studies (Alvarez et al. 1977). The Pv. eugubina Zone is more expanded in all auxiliary sections than in the Gubbio section. The planktic foraminiferal assemblages are more diversified in the Pv. eugubina Zone than in the G. cretacea Zone, but most of the species still are of small size and many of them are failed progenitors that became extinct in the lowermost part of the Ps. 
pseudobulloides Zone. The paleoenvironment recovered in the early part of the Ps. pseudobulloides Zone, the planktic foraminifera reached normal size and some of them became spinose and cancellate, increasing the pore size.

In spite of the controversial disagreements regarding the pattern of extinction of planktic foraminifera discussed in Molina et al. (2006), there is a general agreement regarding the biozonation across the $\mathrm{K} / \mathrm{Pg}$ boundary. This biozonation is as follows: A. mayaroensis Zone for the upper Maastrichtian and G. cretacea, Pv. eugubina and Ps. pseudobulloides zones for the lower Danian. The uppermost Maastrichtian is characterized by the planktic foraminiferal Abathomphalus mayaroensis Zone, according to the biozonation by Caron (1985). This zone was subdivided into three subzones, using an uppermost subzone named Plummerita hantkeninoides Zone by Arz and Molina (2002). The Danian biozonation by Berggren and Pearson (2005) is correlated with that of Arenillas et al. (2004) in order to show the equivalence of the numerical zones with the usual system of nomenclature.

\section{Correlation by other groups}

The small benthic foraminifera biozonation is based on the Berggren and Miller (1989) zonation for the Paleogene, who used only one zone for the entire Paleocene (BB1 for bathyal environments or AA1 for abyssal environments). For the Cretaceous, it has been completed with the Bolivinoides draco Zone by Molina et al. (2006). Bathyal and abyssal foraminifera did not suffer a catastrophic mass extinction. Some species became extinct, but others were protected in certain environments and re-colonized the deep sea when the environment recovered. The main feature of small benthic foraminifera was the reorganization of the community structure due to the drop in primary productivity after the asteroid impact. Whereas benthic foraminiferal and geochemical data indicate low oxygen conditions during the earliest Danian in southeastern Spain (e.g. Caravaca section), no evidence for oxygen deficiency at the sea floor has been found in other sections here described, supporting the local, not global occurrence of anoxic conditions after the K/Pg (Alegret and Thomas, 2005; Alegret, 2007).

The calcareous nannofossils biozonation is based on several studies. The uppermost Maastrichtian is characterized by the Micula prinsii Zone (Percival and Fischer, 1977; Perch-Nielssen, 1979; Romein and Smit, 1981; Perch-Nielssen et al., 1982; Pospichal, 1994; Gardin and Monechi, 1998, among others). There is a general agreement that the calcareous nannoplankton suffered a sudden catastrophic mass extinction at the $\mathrm{K} / \mathrm{Pg}$ boundary and that many Cretaceous specimens are reworked in the Paleogene.

A dinoflagellate zonation and subzonation were established by Brinkhuis and Zachariasse (1988) for the El Kef section, although these authors only studied the lowermost Danian. Dinoflagellates were also studied in the Aïn Settara section by Dupuis et al. (2001), who recognized the Damassadinium californicum Zone for the lowermost Danian. This species first appears $9 \mathrm{~cm}$ above the K/Pg boundary, and a dinocyst peak $(90 \%)$ was found coinciding with the $\mathrm{K} / \mathrm{Pg}$ boundary. The base of the $D$. californicum Zone correlates with the

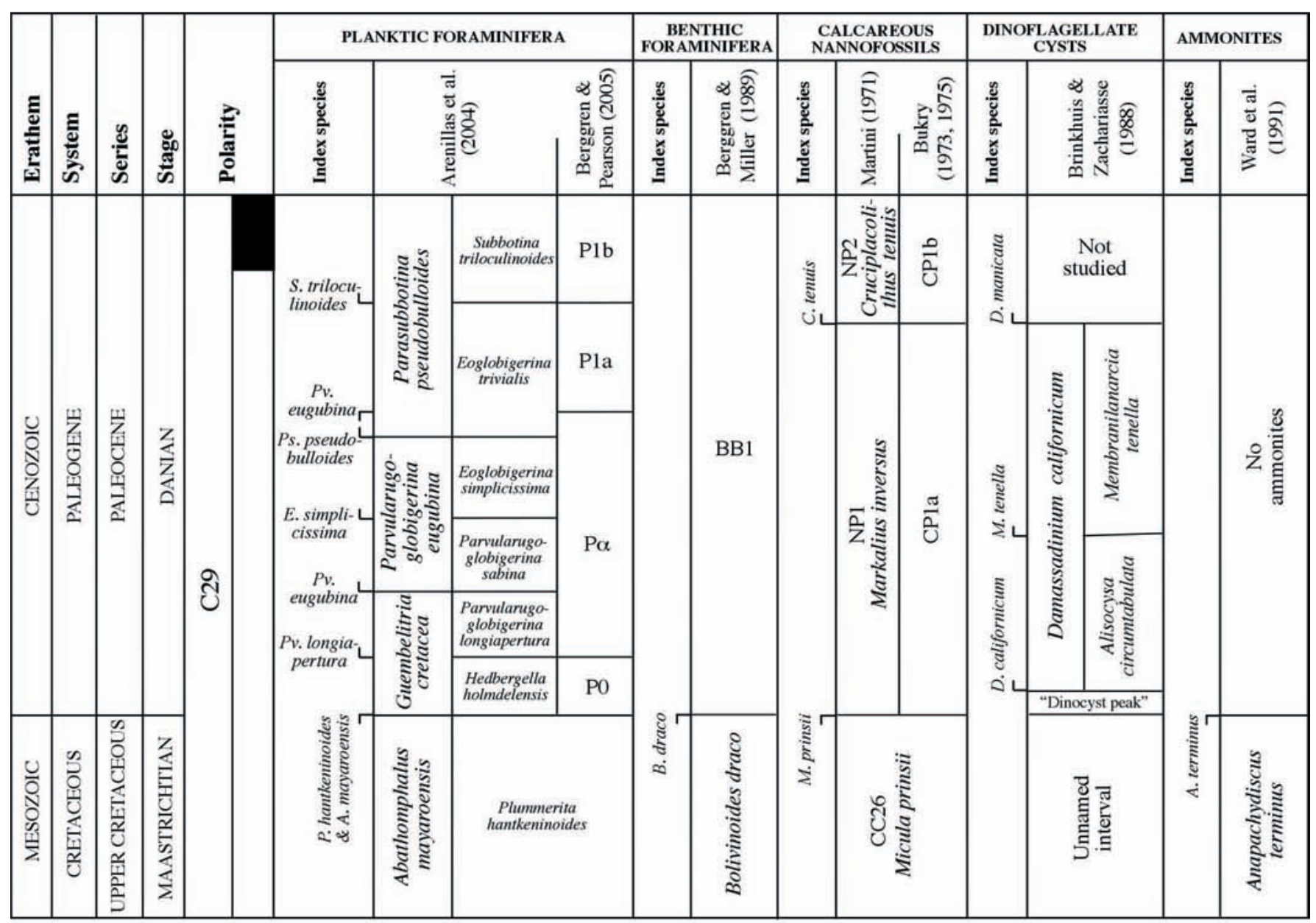

Figure 3. Integrated magnetobiochronologic scale for the K/Pg boundary. 
lowermost part of the planktic foraminifera G. cretacea Zone, which is $60 \mathrm{~cm}$ thick at the Ain Settara section. For practical purposes, it can be concluded that the base of $D$. californicum approximately coincides with the $\mathrm{K} / \mathrm{Pg}$ boundary.

Ammonites are frequent in Zumaya and other sections of the Basque country. They were studied by Ward et al. (1991), who established the coincidence of the extinction with the K/Pg boundary and recognized the Anapachydiscus terminus Zone for the uppermost Maastrichtian. Apparently, ammonites seem to decline before the $\mathrm{K} / \mathrm{Pg}$ boundary, but this is not a relevant argument against the impact theory, because the group eventually became extinct at the $\mathrm{K} / \mathrm{Pg}$ boundary. Moreover, this apparent decline could be due to the taphonomical effect of inappropriate lithology for ammonite fossilization in the auxiliary sections or the methodological SignorLipps effect.

\section{Implications of GSSP level for Cenozoic chronostratigraphy}

We propose the aforementioned sections to be auxiliary sections that allow worldwide correlation of the K/Pg GSSP. Data from all the auxiliary sections allowed us to trace a very detailed integrated magnetobiochronologic scale for the K/Pg boundary (Fig.3). The GSSP for the base of the Danian Stage defines also the base of the Paleocene, Paleogene, "Tertiary" and Cenozoic. The Tertiary used to be a system equivalent to Cretaceous and Quaternary, but it has been replaced by the standard Paleogene and Neogene systems, and the Tertiary is an informal unit no longer used in the Geologic Time Scale (Gradstein et al., 2004). Nevertheless, it has been commonly used in the $\mathrm{K} / \mathrm{Pg}$ boundary literature and can be used as an informal suberathem. The magnetobiochronologic scale of the Paleocene has been recently revised by Berggren and Pearson (2005). This scale is, in general, in agreement with the data provided by the K/Pg GSSP and the auxiliary sections proposed here, although it is incomplete regarding the Cretaceous.

\section{Acknowledgements}

This research was funded by the IUGS, the Spanish Ministerio de Educación y Ciencia (Consolider project CGL2007-63724 and AECI project A/4845/06) and the Aragonian Departamento de Educación y Ciencia (DGA group E05). L. Alegret acknowledges support from a Ramon y Cajal research contract from the Spanish Ministry of Science and Technology.

\section{References}

Adatte, T., Stinnesbeck, W. and Keller, G., 1996, Lithostratigraphic and mineralogic correlations of near $\mathrm{K} / \mathrm{T}$ boundary clastic sediments in northeastern Mexico: Implications for origin and nature of deposition: Geological Society of America, Special Paper, 307, 211-226.

Alegret, L., 2007, Recovery of the deep-sea floor after the Cretaceous/ Paleogene boundary event: the benthic foraminiferal record in the BasqueCantabrian basin and in South-eastern Spain: Palaeogeography, Palaeoclimatology, Palaeoecology, 255(1-2), 181-194.

Alegret, L., and Thomas, E., 2005, Cretaceous/Paleogene boundary bathyal paleo-environments in the central North Pacific (DSDP Site 465), the Northwestern Atlantic (ODP Site 1049), the Gulf of Mexico and the Tethys: The benthic foraminiferal record: Palaeogeography, Palaeoclimatology, Palaeoecology, 224(1-3), 53-82.
Alegret, L., Molina, E., and Thomas, E., 2001, Benthic foraminifera at the Cretaceous/Tertiary boundary around the Gulf of Mexico: Geology, 29(10), 891-894.

Alegret, L., Arenillas, I., Arz, J. A., and Molina, E., 2002a. Eventostratigrafía del límite Cretácico/Terciario en Aïn Settara, Tunicia: disminución de la productividad y/o de la oxigenación oceánicas? Revista Mexicana de Ciencias Geológicas, 19(2), 121-136.

Alegret, L., Arenillas, I, Arz, J. A., Liesa, C., Meléndez, A., Molina, E., Soria, A. R., and Thomas, E., 2002b, The Cretaceous/Tertiary boundary: sedimentology and micropaleontology at El Mulato section, NE Mexico: Terra Nova, 14, 330-336.

Alegret, L., Kaminski, M. A., and Molina, E., 2004a, Paleo-environmental recovery after the Cretaceous/Paleogene boundary crisis: evidence from the marine Bidart section (SW France): Palaios, 19, 574-586.

Alegret, L., Arenillas, I, Arz, J. A., and Molina, E., 2004b, Foraminiferal event-stratigraphy across the Cretaceous/Paleogene boundary: Neues Jarbuch für Geologie und Paläontologie, Ahhandlungen, 234(1-3), 25 50.

Alvarez, L. W., Alvarez, W., Asaro, F., and Michel, H. V., 1980, Extraterrestrial cause for the Cretaceous-Tertiary extinction: Science, 208, 1095-1108.

Alvarez, W., Arthur, M. A., Fischer, A. G., Lowrie, W., Napoleone, G., Premoli Silva, I., and Roggenthen, W. M., 1977, Upper Cretaceous-Paleogene magnetic stratigraphy at Gubbio, Italy. 5. Type section for Late Cretaceous-Paleocene geomagnetic reversal time scale: Geological Society of America Bulletin, 88, (3), 383-388.

Apellaniz, E., Baceta, J. I., Bernaola-Bilbao, G., Núñez-Betelu, K., OrueEtxebarria, X., Payros, A., Pujalte, V., Robin, E., and Rocchia, R., 1997, Analysis of uppermost Cretaceous-lowermost Tertiary hemipelagic successions in the Basque Country (western Pyrenees): evidence for a sudden extinction of more than half planktic foraminifer species at the K/T boundary: Bulletin de la Société géologique de France, 168(6), 783793.

Arenillas, I., Arz, J. A., and Molina, E., 1998, El límite Cretácico/Terciario de Zumaya, Osinaga y Músquiz (Pirineos): control bioestratigráfico y cuantitativo de hiatos con foraminíferos planctónicos: Revista de la Sociedad Geológica de España, 11, no. 1-2, 127-138.

Arenillas, I., Arz, J. A., Molina, E., and Dupuis, C., 2000, The Cretaceous/ Tertiary boundary at Aïn Settara, Tunisia: sudden catastrophic mass extinction in planktic foraminifera: Journal of Foraminiferal Research, 30(2), 202-218.

Arenillas, I., Alegret, L., Arz, J. A., Meléndez, A., Molina, E., Liesa, C., Soria, A. R., Cedillo-Pardo, E., Grajales-Nishimura, J. M., and Rosales, M. C., 2002, Cretaceous/Tertiary boundary planktic foraminiferal mass extinction and biochronology at La Ceiba, Bochil, México, and El Kef, Tunisia: Geological Society of America Special Paper, 356, 253264.

Arenillas, I., Arz, J. A., and Molina, E., 2004, A new high-resolution planktic foraminiferal zonation and subzonation of the lower Danian: Lethaia, 37, 79-95.

Arenillas, I., Arz, J. A. Grajales-Nishimura, M., Murillo-Muñeton, G., Alvarez, W., Camargo-Zanoguera, A., Molina, E., and Rosales-Dominguez, C., 2006, Chicxulub impact event is Cretaceous/Paleogene boundary in age: new micropaleontological evidence: Earth and Planetary Science Letters, 249, 241-257.

Arinobu, T., Ishiwatari, R., Kaiho, K., and Lamolda, M. 1999, Spike of pyrosynthetic polycyclic aromatic hydrocarbons associated with an abrupt decrease in $\delta^{13} \mathrm{C}$ of a terrestrial biomarker at the Cretaceous-Tertiary boundary at Caravaca, Spain. Geology, 27(8), 723-726.

Arz, J. A., and Molina, E., 2002, Bioestratigrafía y Cronoestratigrafía con foraminíferos planctónicos del Campaniense superior y Maastrichtiense de latitudes templadas y subtropicales (España, Francia y Túnez): Neues Jahrbuch fur Geologie und Paläontologie, Monatshefte, 224(2), 161-195.

Arz, J. A., Arenillas, I., Molina, E., and Dupuis, C., 1999a, Los efectos tafonómico y Signor-Lipps sobre la extinción en masa de foraminíferos planctónicos en el límite Cretácico/Terciario de Ellès (Tunicia): Revista de la Sociedad Geológica de España, 12(2), 251-267.

Arz, J. A., Arenillas, I., and Molina, E., 1999b, Extinción de foraminiferos planctónicos en el tránsito Cretácico-Terciario de Zumaya (Guipúzcoa): supervivencia o reelaboración?: Revista Española de Micro-paleontología, 31(3), 297-304.

Arz, J. A., Arenillas, I., Molina, E., and Sepúlveda, R., 2000, La estabilidad evolutiva de los foraminíferos planctónicos en el Maastrichtiense Superior 
y su extinción en el límite Cretácico/Terciario de Caravaca (España): Revista Geológica de Chile, 27(1), 27-47.

Arz, J. A., Alegret, L., and Arenillas, I., 2004, Foraminiferal biostratigraphy and paleoenvironmental reconstruction at Yaxcopoil-1 drill hole (Chicxulub crater, Yucatan Peninsula): Meteoritics \& Planetary Science, 39(7), 1099-1111.

Berggren, W. A., and Pearson, P., 2005, A revised tropical to subtropical Paleocene planktonic foraminiferal zonation: Journal of Foraminiferal Research, 35(4), 279-298.

Bonté, P., Delacotte, O., Renard, M., Laj, C., Bochet, D., Jehanno, C., and Rocchia, R., 1984, An iridium rich layer at the Cretaceous/Tertiary boundary in the Bidart section (southern France): Geophysical Research Letters, 11, 473-476.

Brinkhuis, H., and Zachariasse, W. J., 1988, Dinoflagellate cysts, sea level changes and planktonic foraminifers across the Cretaceous-Tertiary boundary at El Haria, Northwest Tunisia: Marine Micropaleontology, 13, 153-191.

Canudo J. I., Keller J., and Molina, E., 1991, Cretaceous/Tertiary boundary extinction pattern and faunal turnover at Agost and Caravaca, SE Spain: Marine Micropaleontology, 17, 319-341.

Caron, M., 1985, Cretaceous planktic foraminifera, in H.M. Bolli, J.B. Saunders y K. Perch-Nielsen, eds., Plankton Stratigraphy: Cambridge University Press, New York, 1, 17-86.

Coccioni, R., and Galeotti, S., 1994, K-T boundary extinction: Geologically instantaneous or gradual event? Evidence from deep-sea benthic foraminifera: Geology, 22, 779-782.

Coccioni, R., Fabbrucci, L., and Galeotti, S. 1993, Terminal Cretaceous deepwater benthic foraminiferal decimation survivorship and recovery at Caravaca (SE Spain): Paleopelagos, 3, 3-24.

Delacotte, O., Renard, M., Laj, C., Perch-Nielsen, K., Permoli-Silva, I., and Clauser, S., 1985, Magnètostratigraphie et biostratigraphie du passage Crétacé-Tertiaire de la coupe de Bidart (Pyrenées Atlantiques): Bulletin des Centres de Recherches Géologiques et Minières 1, Géologie de la France, 3, 243-254.

De Paolo, D. J., Kyte, F.T., Marshall, B. D. O’Neill, J. R., and Smit, J., 1983, $\mathrm{Rb}-\mathrm{Sr}, \mathrm{Sm}-\mathrm{Nd}, \mathrm{K}-\mathrm{Ca}, \mathrm{O}$ and $\mathrm{H}$ isotopic study of Cretaceous-Tertiary boundary sediments, Caravaca, Spain: evidence of an oceanic impact site: Earth and Planetary Science Letters, 64, 356-373.

Dupuis, C., Steurbaut, E., Molina, E., Rauscher, R., Tribovillard, N., Arenillas, I., Arz, J. A., Robaszynski, F., Caron, M., Robin, E., Rochia, R. and Lefevre, I., 2001, The Cretaceous-Paleogene (K/P) boundary in the Ain Settara section (Kalaat Senan, Central Tunisia): lithological, micropaleontological and geochemical evidence: Bulletin de l'Institut royal des Sciences naturelles de Belgique: Sciences de la Terre, 71, 169190 .

Ekdale, A. A., and Stinnesbeck, W., 1998, Trace Fossils in Cretaceous-Tertiary (KT) boundary beds in northeastern Mexico: Implication for sedimentation during the KT boundary event: Palaios, 13, 593-602.

Fondecave-Wallez, M. J., Peybernès, B., and Eichène, P., 1995a, Essai de caractérisation sédimentologique et micropaléontologique de la limite Crétacé - Tertiaire dans la coupe de Zumaya (Pays Basque espagnol): Bulletin de la Société de Histoire Naturelle de Toulouse, 131, 91-98.

Fondecave-Wallez, M. J., Peybernès, B., and Eichène, P., 1995b, Mise en évidence micropaléontologique d'un flysch ypréso-lutétien, excrétacé, à matériel triasique resédimenté, dans la coupe de Bidart Nord (Pyrénées atlantiques, Sud-Ouest de la France): Géologie de la France, 3, 47-56.

Galbrun, B., 1997, Normal polarity magnetic overprint of chron C29r by diagenetic hematite growth in red marly limestones from Bidart and Loya sections (Pays-Basque, France): Terra Nova, 9, 314.

Galbrun, B., and Gardin, S., 2004, New chronostratigraphy of the CretaceousPaleogene boundary interval at Bidart (France): Earth and Planetary Science Letters, 224, 19-32.

Gardin, S., 2002, Late Maastrichtian to early Danian calcareous nannofossils at Ellès (Northwest Tunisia). A tale of one million years across the K-T boundary: Palaeogeography, Palaeoclimatology, Palaeoecology, 178(34), 211-231.

Gardin, S., and Monechi, S., 1998, Palaecological change in middle to low latitude calcareous nannoplankton at the Cretaceous/Tertiary boundary. Bulletin de la Société géologique de France, 169(5), 709-723.

Gorostidi, A., and Lamolda, M. A., 1995, La nanoflora calácrea y el tránsito KT de la sección de Bidart (SW de Francia): Revista Española de Paleontología no. Homenaje a Colom, 153-168.
Gradstein, F., Ogg, J., and Smith, A. eds. 2004, A Geologic Time Scale: Cambridge University Press, 598p.

Grajales-Nishimura, J. M., Cedillo, E., Rosales, M. C., Morán, D. J., Alvarez, W., Claeys, P., Ruiz, J. García, J., Padilla, P., and Sánchez, A., 2000, Chicxulub impact: The origin of reservoir and seal facies in the southeastern Mexico oil field: Geology, 28, 307-310.

Grajales-Nishimura, J. M., Murillo-Muñetón, G., Rosales-Domínguez, C., Cedillo-Pardo, E., and Hernandez-Garcia, J., 2003, Heterogeneity of lithoclast composition in the deep-water carbonate breccias of the K/T boundary sedimentary succession, southeastern Mexico and offshore Campeche, in Bartollini, C., Buffler, R.T., and Blickwede, J.F., eds., The Circum-Gulf of Mexico and the Caribbean. Hydrocarbon Habitats, Basin Formation, and Plate Tectonics: American Association of Petroleum Geologists, Memoir 79, 312-329.

Haslett, S. K., 1994, Planktonic foraminiferal biostratigraphy and paleoceanography of the Cretaceous-Tertiary boundary section at Bidart, south-west France: Cretaceous Research, 15, 179-192.

Kaiho, K., and Lamolda, M., 1999, Catastrophic extinction of planktonic foraminfera at the Cretaceous-Tertiary boundary evidenced by stable isotopes and foraminiferal abundance at Caravaca, Spain: Geology, 27(4), 355-358.

Karoui-Yaakoub, N., Zaghbib-Turki, D., and Keller, G., 2002, The CretaceousTertiary (K-T) mass extinction in planktic foraminifera at Elles I and El Melah, Tunisia: Palaeogeography, Palaeoclimatology, Palaeoecology, 178(3-4), 233-255.

Keller, G., 1989, Extended Cretaceous/Tertiary boundary extinctions and delayed population change in planktonic foraminifera from Brazos River: Paleoceanography, 4(3), 287-332.

Keller, G., Adatte, T., Stinnesbeck, W., Luciani, V., Karoui-Yaakoub, N., and Zaghbib-Turki, D., 2002, Paleoecology of the Cretaceous-Tertiary mass extinction in planktonic foraminifera: Palaeogeography, Palaeoclimatology, Palaeoecology, 178, 257-295.

Keller, G., Stinnesbeck, W., Adatte, T., and Stüben, D., 2003, Multiple impacts across the Cretaceous - Tertiary boundary: Earth-Science Reviews, 62, 327-363.

Keller, G., Adatte, T., Stinnesbeck, W., Stüben, Berner, Z., Kramar, U., and Harting, D., 2004, More evidence that the Chicxulub impact predates the K/T mass extinction: Meteoritics and Planetary Science, 39(7), 11271144 .

Kuhnt, W., and Kaminski, M. A., 1993, Changes in the community structure of deep water agglutinated foraminifers across the $\mathrm{K} / \mathrm{T}$ boundary in the Basque Basin (Northern Spain): Revista Española de Micropaleontología, $25,57-92$

Kyte, F.C., Smit, J., and Wasson, J. T., 1985, Siderophile interelement variations in the Cretaceous-Tertiary boundary sediments from Caravaca, Spain: Earth and Planetary Science Letters, 73, 183-195.

Lamolda, M. A., 1990, The Cretaceous-Tertiary boundary crisis at Zumaya (northern Spain) micropaleontological data, in Kauffman, E.G. and Walliser, O.H. eds., Extinction events in Earth History: Lecture Notes in Earth Sciences, 30, 393-399.

López-Oliva, J. G., and Keller, G., 1996, Age and stratigraphy of near-K/T boundary siliciclastic deposits in northeastern Mexico: Geological Society of America, Special Paper, 307, 227-242.

Luciani, V., 2002, High-resolution planktonic foraminiferal analysis from the Cretaceous-Tertiary boundary at Ain Settara (Tunisia): evidence of an extended mass extinction: Palaeogeography, Palaeoclimatology, Palaeoecology, 178(3-4), 299-319.

Luterbacher, H. P., and Premoli Silva, I., 1964, Biostratigrafia del limite Cretaceo-Terciario nell'Apennino Centrale: Rivista Italiana di Paleontologia e Stratigrafia, 70(1), 67-128.

Martínez Ruiz, F. C., Ortega Huertas, M., Palomo, I., and Acquafredda, P., 1997, Quench textures in altered spherules from the Cretaceous-Tertiary boundary layer at Agost and Caravaca, SE Spain: Sedimentary Geology, 113, 137-147.

Martini, E., 1961, Nannoplankton aus dem Tertiaer und der obersten Kreide von SW-Frankreich: Senckenbergiana Lethaea, 42, 1-32.

Minoletti, F., Rafaelis, M., Renard, M., and Gardin, S., 2004, Reworking of Maastrichtian-like calcareous nannofossils in the lowermost Danian sediments of Bidart section (France): isotopic evidence (carbon and oxygen): Revue de Micropaleontologie, 47, 145-152.

Molina, E., Arenillas, I., and Arz, J. A., 1998, Mass extinction in planktic foraminifera at the Cretaceous/Tertiary boundary in subtropical and 
temperate latitudes: Bulletin de la Société géologique de France, 169(3), 351-363.

Molina, E., Alegret, L., Arenillas, I., Arz, J. A., Gallala, N., Hardenbol, J., von Salis, K., Steurbaut, E., Vandenberghe, N., and Zaghbib-Turki, D., 2006, The Global Boundary Stratotype Section and Point for the base of the Danian Stage (Paleocene, Paleogene, "Tertiary", Cenozoic) at El Kef, Tunisia: Original definition and revision: Episodes, 29(4), 263-273.

Montanari, A., Hay, R. L., Alvarez, W., Asaro, F., Michel, H. V., Alvarez, L. W., and Smit, J. 1983, Spheroids at the Cretaceous-Tertiary boundary are altered impact droplets of basaltic composition. Geology, 11, 668671.

Montanari, A., Claeys, P., Asaro, F., Bermúdez, J., and Smit, J., 1994, Preliminary stratigraphy and iridium and other geochemical anomalies across the KT boundary in the Bochil section (Chiapas, southeastern Mexico): Lunar Planetary Institute Contributions, Houston, 825, 84-85.

Mount, J. F., Margolis, S. V., Showers, W., Ward, P., and Doehne, E., 1986, Carbon and oxygen isotope stratigraphy of the upper Maastrichtian, Zumaya, Spain: A record of Oceanographic and Biologic Changes at the end of the Cretaceous Period: Palaios, 1, 87-92.

Mukhopadhyay, S., Farley, K. A., and Montanari, A., 2001, A short duration of the Cretaceous-Tertiary boundary event: Evidence from extraterrestrial Helium-3: Science, 291, 1952-1955.

Nelson, B. K., MacLeod, G. K., and Ward, P. D., 1991, Rapid change in strontium isotopic composition of sea water before the Cretaceous/Tertiary boundary: Nature, 351, 644-647.

Norris, R. D., Klaus, A., Kroon, D., and the Leg 171B Science Party., 2001, Mid-Eocene deep water, the Late Palaeocene Thermal Maximum and continental slope mass wasting during the Cretaceous-Palaeogene impact, in Kroon, D., Norris, R.D. and Klaus, A. eds., Western North Atlantic Palaeogene and Cretaceous Palaeoceanography: Geological Society of London Special Publication, 183, 23-48.

Ortega Huertas, M., Martínez Ruiz, F., Palomo, I., and Chanley, H., 1995, Comparative mineralogical and geochemical clay sedimentation in the Betic Cordilleras and Basque-Cantabrian Basin areas at the CretaceousTertiary boundary: Sedimentary Geology, 94, 209-227.

Perch-Nielsen, K., 1979, Calcareous nannofossils at the Cretaceous/Tertiary boundary near Biarritz, France, in Christensen, W. K., ed., CretaceousTertiary boundary events: University of Copenhagen, 2, 151-155.

Perch-Nielsen, K., Mckenzie, J., and He, Q., 1982, Biostratigraphy and isotope stratigraphy and the catastrophic extinction of calcareous nannoplankton at the Cretaceous/Tertiary boundary: Geological Society of America, Special Paper, 190, 353-371.

Percival, S. F., and Fischer, A. G., 1977, Changes in calcareous nannoplankton in the Cretaceous-Tertiary biotic crisis at Zumaya, Spain: Evolution Theory, 2, 1-35.

Peryt, D., Alegret, L., and Molina, E., 2002, The Cretaceous/Paleogene (K/P) boundary at Aïn Settara, Tunisia: restructuring of benthic foraminiferal assemblages: Terra Nova, 14, 101-107.

Peryt, D., Alegret, L., and Molina, E., 2004, Agglutinated foraminifers and their response to the Cretaceous/Paleogene boundary event at Aïn Settara, Tunisia, in M. Bubik y M. Kaminski, eds. Proceeding of the VI International Workshop on Agglutinated Foraminifera: Grzybowski Fundation Special Publication, 8, 393-412.

Peybernès, B., Fondecave-Wallez, M. J., Eichène, P., Bost, J., Sibe, B., Marais, M., and Quilès, G., 1996, La limite Crétacé-Paléocène: phénomènes biologiques, événements géologiques d'après les sites de la côte basque: Centre régional de documentation pédagogique d’Aquitaine, Bordeaux, $91 \mathrm{p}$.

Peybernès, B., Fondecave-Wallez, M. J., Gourinard, Y., and Eichene, P., 1997, Stratigraphie sequentielle comparèe et grade-datation par les foraminiferes planctoniques du Campano-Maastrichtien et du Paleocene de quelques sites d'Europe sud-occidentale et d'Afrique du Nord. Comptes Rendues de la Academie de Sciences, Serie D, Sciences Terre, 324, 839-846.

Pospichal, J. J., 1994, Calcareous nannofossils at the K-T boundary, El Kef: No evidence for stepwise, gradual, or sequential extinctions: Geology, 22, 99-102.

Pospichal, J. J., 1996, Calcareous nannofossils and clastic sediments at the Cretaceous-Tertiary boundary, northeastern Mexico: Geology, 24, 255258.

Rampino, M., and Reinolds, R.C., 1983, Clay mineralogy of the CretaceousTertiary boundary clay: Science, 219, 495-498.
Remane, J, Bassett, M. G., Cowie, J. W., Gohrbandt, K. H., Lane, H. R., Michelsen, O., and Niwen, W., 1996, Revised guidelines for the establishment of global chronostratigraphic standards by the International Commission on Stratigraphy (ICS): Episodes, 19, 77-80.

Remane, J., and Adatte, T., eds., 2002, Cretaceous-Paleogene transition in Tunisia, May 1998: Palaeogeography, Palaeoclimatology, Palaeoecology, 178(3-4), 137-345.

Renard, M., Delacotte, O., and Létolle, R., 1982, Le strontium et les isotopes stables dans les carbonates totaux de quelques sites de l'Atlantique et de la Tethys: Bulletin de la Société géologique de France, 14, 519-534.

Robin, E., Boclet, D., Bonte, P., Froget, L., Jehanno, C., and Rocchia, R., 1991, The stratigraphic distribution of Ni-rich spinels in CretaceousTertiary boundary rocks at El-Kef (Tunisia), Caravaca (Spain) and Hole761C(Leg-122): Earth and Planetary Science Letters, 107(3-4), 715-721.

Rocchia, R., Boclet, D., Bonte, P., Devineau, J., Jehanno, C., and Renard, M., 1987, Comparison des distributions de l'iridium observées la limite Crétacé-Tertiaire dans divers sites Européens: Memoires de la Societé Géologique de France, 150, 95-103.

Rodriguez-Tovar, F. J., and Uchman, A., 2006, Ichnological analysis of the Cretaceous-Palaeogene boundary interval at the Caravaca section, SE Spain: Palaeogeography, Palaeoclimatology, Palaeoecology, 242(3-4), 313-325.

Romein, A. J. T., and Smit, J., 1981, The Cretaceous/Tertiary boundary: calcareous nannofossil and stable isotopes: Proceedings Koninklijke Nederlandse Akademie van Wetenschappen, 84, 295-314

Saïd-Benzarti, R., 1998, Les ostracodes du Campanien-supérieur à l'Yprésien de la coupe d'Ellès (Tunisie du Centre-nord) : Biostratigraphie, Paléoécologie et Paléogéographie: Bulletin Elf Aquitaine, 20, 97-211.

Sánchez-Ríos, M. A., Ruíz, H., Padilla, P., Jiménez, T., and Martínez, R. 1993, El nanoplancton calcáreo y los foraminíferos planctónicos del límite K/T de la sección El Mulato, Estado de Tamaulipas, México: Revista de la Sociedad Mexicana de Paleontología, 6, 43-65.

Schmitz, B., 1994, Geochemical high-resolution stratigraphy of Cretaceous/ Tertiary boundary in Denmark, Spain and New Zealand, in Molina E., ed., Extinción y registro fósil. Extinction and the fossil record: SIUZ Cuadernos Interdisciplinares, 5, 121-140.

Seyve, C., 1990, Nannofossil biostratigraphy of the Cretaceous-Tertiary boundary in the French Basque Country: Bulletin Elf-Aquitaine, 14, 553 572

Shukolyukov, A., and Lugmair, G. W., 1998, Isotopic evidence for the Cretaceous-Tertiary impactor and its type: Science, 282, 927-929.

Smit, J., 1977, Discovery of a planktonic foraminiferal association between the Abathomphalus mayaroensis Zone and the "Globigerina" eugubina Zone at the Cretaceous/Tertiary boundary in the Barranco del Gredero (Caravaca, SE Spain): A preliminary report: Proceedings of the Koninklijke Nederlandse Akademie van Wetershcappen, ser. B, 80(4), 280-301.

Smit, J., 1979, The Cretaceous/Tertiary transition in the Barranco del Gredero, Spain, in Christensen W.K. and Birkelund. eds., Proceedings C-T boundary events Symposium, II, 156-163.

Smit, J., 1999, The global stratigraphy of the Cretaceous-Tertiary boundary impact ejecta: Annual Reviews of Earth Planetary Sciences, 27, 75-113.

Smit, J., and Hertogen J., 1980, An extraterrestrial event at the CretaceousTertiary boundary: Nature, 285, 198-200

Smit, J., and Klaver, G., 1981, Sanidine spherules at the Cretaceous-Tertiary boundary indicate a large impact event: Nature. 292, 47-49.

Smit, J., and Romein, A. J. T., 1985, A sequence of events across the Cretaceous-Tertiary boundary: Earth and Planetary Science Letters, 74, 155-170.

Smit, J., and ten Kate, W. G. H. Z., 1982, Trace-element patterns at the Cretaceous-Tertiary boundary. Consequences of a large impact: Cretaceous Research, 3, 307-332.

Smit, J., Montanari, A., Swinburne, N. H. M., Alvarez, W., Hildebrand, A. R., Margolis, S. V., Claeys, P. F., Lowrie, W., and Asaro, F., 1992, Tektitebearing, deep-water clastic unit at the Cretaceous-Tertiary boundary in northeastern Mexico: Geology, 20(2), 99-103.

Smit, J., Roep, T. B., Alvarez, W., Montanari, A., Claeys, P., GrajalesNishimura, J. M., and Bermudez, J., 1996, Coarse-grained, clastic sandstone complex at the K/T boundary around the Gulf of Mexico: Deposition by tsunami waves induced by the Chicxulub impact? in Ryder, G., et al., eds., The Cretaceous-Tertiary event and other catastrophes in Earth history: Geological Society of America, Special Paper, 307, 151-182. 
Soria, A. R., Liesa, C., Mata, P., Arz, J. A., Alegret, L., Arenillas, I., and Meléndez, A., 2001, Slumping and a sandbar deposit at the K/T boundary in the El Tecolote sector (northeastern Mexico): An impact-induced sediment gravity flow: Geology, 29, 231-234.

Soria, A. R., Liesa, C., Mata, P., Arz, J. A., Alegret, L., Arenillas, I., and Meléndez, A., 2002, Slumping and a sandbar deposit at the K/T boundary in the El Tecolote sector (northeastern Mexico): An impact-induced sediment gravity flow- Reply: Geology, 30, 383-383.

Stüben, D., Kramar, U., Berner, Z., Stinnesbeck, W., Keller, G., and Adatte, T., 2002, Trace elements, stable isotopes, and clay mineralogy of the Elles II K-T boundary section in Tunisia: indications for sea level fluctuations and primary productivity: Palaeogeography, Palaeoclimatology, Palaeoecology, 178(3-4), 321-345.

Vannuci, S., Pancani, M. G., Vaselli, O., and Caradosi, N., 1990, Mineralogical and geochemical features of the Cretaceous-Tertiary boundary in the Barranco del Gredero section (Caravaca, SE Spain); Chemical Erde, 50, 189-202.

Ward, P. D., 1988, Maastrichtian ammonite and inoceramid ranges from Bay of Biscay Cretaceous-Tertiary boundary sections, in Lamolda, M.A., Kauffman, E.G., Walliser, O.H. eds., Palaeontology and Evolution; Extinction: Revista Española de Paleontología, no. extr., 119-126

Ward, P. D., and Kennedy, W. J., 1993, Maastrichtian ammonites from the

Eustoquio Molina is full professor of Paleontology (Micro-paleontology) in the Department of Earth Sciences, University of Zaragoza, Spain, and is Chairman of the International Subcommission on Paleogene Stratigraphy. He obtained his degree in Geology and his PhD in Paleontology from the University of Granada. His research includes detailed biostratigraphic studies of the Upper Cretaceous, Paleogene and Lower Neogene planktic foraminifers mainly from the Tethys region. His research concentrated on their use in Chronostratigraphy, Evolution and Extinction.

José Manuel Grajales-Nishimura is full time researcher at the Mexican Institute of Petroleum. He obtained his bachelor degree at the Polytechnic Institute, Mexico City, his MSc degree at the Geo-sciences Department of the University of Arizona (USA) and his PhD at the National University (UNAM), Mexico City. His research includes stratigraphy, sedimentology, diagenesis and geochemistry of carbonate sedimentary sequences, and petrography of impact minerals.

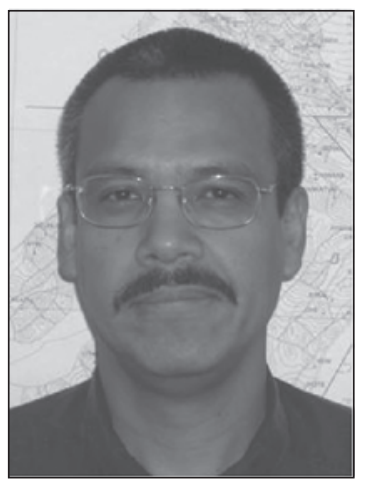

Biscay region (France, Spain): Memoirs of the Paleontolological Society, $34,1-58$.

Ward, P. D., Wiedmann J., and Mount, J. F., 1986, Maastrichtian molluscan biostratigraphy and extinction patterns in a Cretaceous/Tertiary boundary section exposed at Zumaya: Geology, 14, 899-903.

Ward, P. D., Kennedy, W. J., MacLeod, K. G., and Mount, J. F., 1991, Ammonite and inoceramid bivalve extinction patterns in Cretaceous/ Tertiary boundary sections of the Biscay region (southwestern France, northern Spain: Geology, 19, 1181-1184.

Zaghbib-Turki, D., and Karoui-Yaakoub, N., 2004, The Cretaceous-Tertiary (K-T) boundary in Ellès and the other Tunisian outcrops: $32^{\text {nd }}$ International Geological Congress, Florence, Italy, Field Trip Guide Book, P60, $1-28$.

Zaghbib-Turki, D., Karoui-Yaakoub, N., Rocchia, R., Robin, E., and Belayouni, H., 2000, Enregistrement des événements remarquables de la limite Crétacé-Tertiaire dans la coupe d'Ellès (Tunisie): Comptes Rendus de l'Académie des Sciences, Paris, Sciences de la Terre et des Planètes, 331, 141-149.

Zaghbib-Turki, D., Karoui-Yaakoub, N., Said-Benzarti, R., Rocchia, R., and Robin, E., 2001, Révision de la limite Crétace-Tertiaire de la coupe d'Ellès (Tunisie): proposition d'un nouveau parastratotype: Geobios, 34(1), 2537.

Dalila Zaghbib-Turki is full professor of Paleoecology-Micropaleontology in the Department of Geology, Sciences Faculty, University of Tunis El Manar, Tunisia. Her research includes detailed biostratigraphic studies of the Upper Cretaceous and Paleogene planktic and small benthic foraminifers, mainly from Tunisia. Her research concentrated on the use of these microfossils in Chronostratigraphy, Paleogeography, Paleoecology and Extinction.

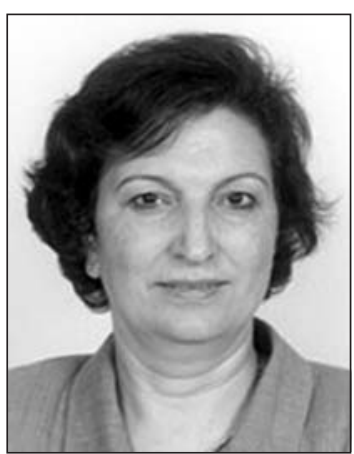

